\title{
Effect of Increasing Sea Water Temperature on Performance of Steam Turbine of Muara Tawar Power Plant
}

\author{
Nastopo Darmawan ${ }^{1}$ and Triyogi Yuwono ${ }^{2}$
}

\begin{abstract}
Muara Tawar Power Plant is located on the coast of Bekasi, West Java, Indonesia. Along with the economic development, there are plans to do reclamation the sea around Muara Tawar Power Plant and build around it as a port and industrial estate. This could potentially lead to an increase in sea water temperatures. This paper aims to determine the effect of increasing sea water temperature on the performance of steam turbine 1.4 in Muara Tawar Power Plant, which uses sea water as a condenser cooling medium. The intended performance is the output power of the steam turbine, the condenser pressure and the system efficiency. Steam turbine 1.4 has $225 \mathrm{MW}$ installed output power, supplied from 3 HRSG (Heat Recovery Steam Generator).Analysis of the effect of sea water temperature rise on steam turbine performance is carried out by using the cycle-tempo software. The main equipment of steam turbine is modeled in cycle-tempo, then model is validated by comparing with design data. Varies sea water temperature then is inputted on model in order to obtain the output power of steam turbine, condenser pressure and system efficiency. The results show that for every $1^{\circ} \mathrm{C}$ increase in condenser cooling water temperature extracted from seawater near the plant, the output power of the plant decreased by about $0.171 \%$, the condenser pressure increased by about $5.146 \%$, and the system efficiency decreased by about $\mathbf{0 . 1 6 8 \%}$.
\end{abstract}

Keywords — Sea Water Temperature, Steam Turbine Performance, Cycle-Tempo Modeling.

\section{INTRODUCTION}

$\mathrm{T}$ he Muara Tawar Power Plant Area consists of 5 blocks of power plant. Block \#1 is combined cycle power plant, consists of 3 gas turbines, 3 Heat Recovery Steam Generators (HRSG) and 1 steam turbine. While Block \#2, \#3, \#4 is open cycle gas turbine and Block \#5 is combined cycle power plant consists of 1 gas turbine, $1 \mathrm{HRSG}$ and 1 steam turbine. Muara Tawar Power Plant is located on the coast of Bekasi, West Java, Indonesia, and this power plant uses seawater near the coast as a condenser-cooling medium.

Along with the economic development and limited land, it is possible that the reclamation of the sea becomes a necessity, and therefore there are plans from the Jakarta government to carry out sea reclamation, around the Muara Tawar Power Plant site, to become ports and industrial estates. This could potentially lead to cause an increase in seawater temperature, and an increase in seawater temperature probably could decrease the output power of steam turbine. The author [1] studied the influence of condenser cooling water temperature on the thermal efficiency of a nuclear power plant in Egypt. The author proved that an increase of one degree Celsius in temperature of the cooling water extracted from environment is forecasted to decrease by $0.444 \%$ and $0.152 \%$ in the power output and the thermal efficiency of the nuclear-power plant considered, respectively. So, it is important to propose a study on the influence of increasing sea water on the performance of steam turbine of Muara Tawar Power Plant.

The aim of this proposed study is to investigate the effect of increasing seawater temperature which is used as a condenser cooling medium on the performance of

${ }^{1}$ Nastopo Darmawan is with staff of PT. Pembangkitan Jawa Bali (PT. PJB), Indonesia. E-mail: nastopo@ptpjb.com.

${ }^{2}$ Triyogi Yuwono is with Department of Mechanical Engineering, Institut Teknologi Sepuluh Nopember, Surabaya, 60111, Indonesia. Email: triyogi@me.its.ac.id. steam turbine 1.4 at Muara Tawar Power Plant. It is carry out by using the Cycle-tempo Software.

\section{METHOD}

\section{A. Modeling}

Modeling methods have been widely used to determine the efficiency and performance of systems or power plants. Many previous studies used modeling methods to analyze the performance of a system. The authors [2] conducted dynamic modeling of the steam power cycle. Dynamic modeling, simulation and optimization of subcritical steam power plants are also implemented by the authors [3]. The authors [4] performed modeling and simulation of coal-fired power plants for start-up optimization.

In this study, steam turbine 1.4 of Muara Tawar Power Plant is modeled and simulated by using Cycle-Tempo 5.1 software, a flow sheeting program for the evaluation and optimization of energy conversion systems, developed at the Delft University of Technology [5]. Modeling using cycle-tempo has also been conducted in a lot of previous studies. The authors [6] conducted research on thermodynamic model of a downdraft gasifier. While, the authors [7] performed research on experimental prototype development and performance analysis of a small-scale combined cycle for energy generation from biomass. Also, the authors [8] conducted research on simulation and parametric optimization of thermal power plant cycles.

In this modeling, only main equipment is considered in the model, but it is not affect too much in the validity of the model. HRSG as steam generator is modeled as boiler (high-pressure boiler and low-pressure boiler), as seen in Fig 1. Data for modeling input is taken form design data, that is Muara Tawar Combine Cycle Power Plant (CCPP) heat balances from manufacturer [9]. Where the data for modeling is:

1. HP steam pressure, temperature and flow

2. LP steam pressure, temperature and flow 


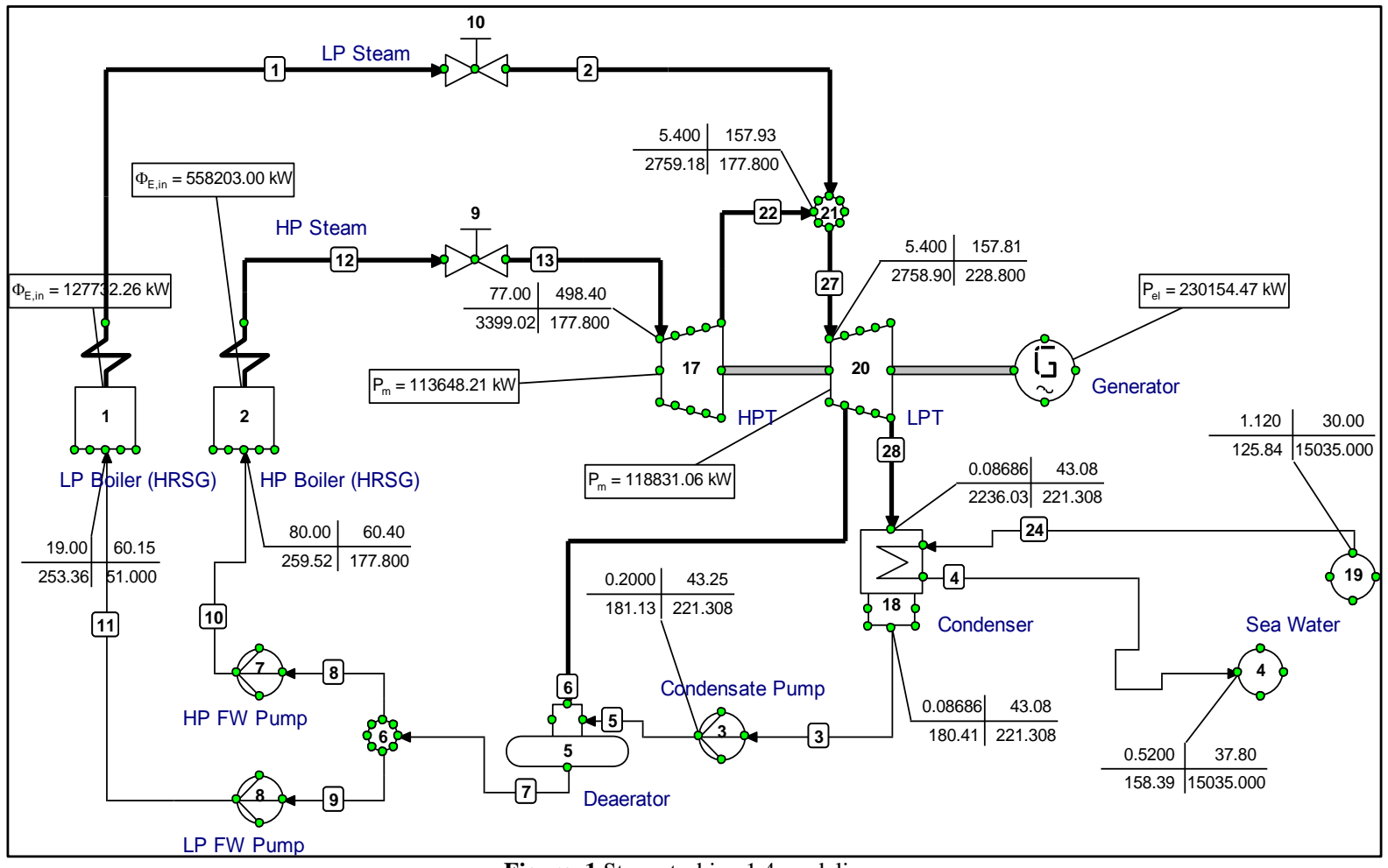

Figure. 1 Steam turbine 1.4 modeling.

3. Sea water inlet and outlet temperature

4. Sea water flow

While output of modeling is:

1. Steam turbine power output

2. Condenser pressure

3. System efficiency

\section{B. Heat Balance Equations}

The energy balance equations for the processes involving steady-flow equipment such as turbines, pumps, steam generator and condenser in the power plant are:

1) The total turbine work

$$
\mathrm{W}_{\mathrm{T}}=\dot{\mathrm{m}}_{\mathrm{st}}\left(\mathrm{h}_{\mathrm{inT}}-\mathrm{h}_{\text {outT }}\right) \text {. }
$$

where :

WT : thetotal turbine work $(\mathrm{kW})$;

mist : steam mass flow rate inlet to turbine $(\mathrm{kg} / \mathrm{s})$;

hinT : enthalpy of steam inlet to turbine $(\mathrm{kJ} / \mathrm{kg})$;

houtT : enthalpy of steam outlet from turbine $(\mathrm{kJ} / \mathrm{kg})$.

2) The total pumping work

$$
\mathrm{WP}=\dot{\mathrm{m} f w}(\text { houtP }- \text { hinP }) \text {. }
$$

where :

WP : thetotal pumping work $(\mathrm{kW})$;

mfw : feed water mass flow rate inlet to pump $(\mathrm{kg} / \mathrm{s})$;

hinP : enthalpy of feed water inlet to pump $(\mathrm{kJ} / \mathrm{kg})$;

houtP : enthalpy of feed water outlet from pump (kJ/kg).

3) Heat added to steam generator

$$
\text { Qin }=\text { mst (houtB }- \text { hinB }) \text {. }
$$

where :

Qin : heat added to steam generator $(\mathrm{kW})$;

mst : steam mass flow rate exit from steam generator $(\mathrm{kg} / \mathrm{s})$;

hinB : enthalpy of feed water inlet to steam generator $(\mathrm{kJ} / \mathrm{kg})$;
houtB : enthalpy of steam outlet from steam generator $(\mathrm{kJ} / \mathrm{kg})$.

4) Heat rejected from condenser

Qout $=\dot{m} m i x \cdot h i n C-\dot{m} f w \cdot h o u t C$.

where :

Qout : heat rejected from condenser $(\mathrm{kW})$;

mmix : mixture mass flow rate inlet to condenser (kg/s);

$\dot{\mathrm{mfw}}$ : feed water mass flow rate outlet from condenser $(\mathrm{kg} / \mathrm{s})$;

hinC : enthalpy of mixture inlet to condenser $(\mathrm{kJ} / \mathrm{kg})$; houtC : enthalpy of feed water outlet from condenser $(\mathrm{kJ} / \mathrm{kg})$.

5) Efficiency of the system

$$
\eta=\frac{W_{n e t}}{Q_{\text {in }}}=\frac{W_{T}-W_{P}}{Q_{\text {in }}} .
$$

where :

$\eta \quad$ : efficiency of the system;

Wnet : the total achieved net work $(\mathrm{kW})$.

\section{Validation}

Model validation is conducted by comparing the modeling result with the design data existing (heat balance), resumed in Table 1.

From resumed table 1 below, the most deviated value is condenser pressure that is $2.188 \%$. This may be caused of limitation data input to the condenser. Anyway, the model is considered as a valid model because the deviation from design data is less than $5 \%$.

\section{RESULTS AND DISCUSSION}

Based on the model that has been validated above, then conducted the data input to the model, sea water temperature variation from $30^{\circ} \mathrm{C}$ up to $34^{\circ} \mathrm{C}$. It should be noted that the design of sea water temperature is $30^{\circ} \mathrm{C}$. Table 2, 3 and 4 show the results of the modeling for the 
TABLE 1.

COMPARISON BETWEEN MODELING RESULT AND DESIGN DATA

\begin{tabular}{lcccc}
\hline \hline \multicolumn{1}{c}{ Parameter } & Unit & $\begin{array}{c}\text { Design } \\
\text { Data }\end{array}$ & $\begin{array}{c}\text { Modeling } \\
\text { Data }\end{array}$ & Deviation \\
\hline $\begin{array}{l}\text { Power Output } \\
\text { HP Steam }\end{array}$ & $\mathrm{kW}$ & 230300 & 230154.47 & $-0.063 \%$ \\
$\begin{array}{l}\text { Pressure } \\
\text { HP Steam }\end{array}$ & $\mathrm{bar}$ & 77 & 77 & $0 \%$ \\
$\begin{array}{l}\text { Temperature } \\
\text { HP Steam }\end{array}$ & ${ }^{\circ} \mathrm{C}$ & 498.4 & 498.4 & $0 \%$ \\
$\begin{array}{l}\text { Flow } \\
\text { LP Steam }\end{array}$ & $\mathrm{kg} / \mathrm{s}$ & 177.8 & 177.8 & $0 \%$ \\
$\begin{array}{l}\text { Pressure } \\
\text { LP Steam }\end{array}$ & $\mathrm{bar}$ & 5.4 & 5.4 & $0 \%$ \\
$\begin{array}{l}\text { Flow } \\
\text { Condenser }\end{array}$ & $\mathrm{kg} / \mathrm{s}$ & 157.4 & 157.81 & $0.26 \%$ \\
$\begin{array}{l}\text { Pressure } \\
\text { Sea Water }\end{array}$ & $\mathrm{bar} . \mathrm{a}$ & 0.085 & 0.08686 & $2.188 \%$ \\
$\begin{array}{l}\text { Inlet Temp. } \\
\text { Sea Water }\end{array}$ & ${ }^{\circ} \mathrm{C}$ & 30 & 30 & $0 \%$ \\
$\begin{array}{l}\text { Outlet Temp. } \\
\text { Sea Water }\end{array}$ & $\mathrm{o}$ & 37.8 & 37.8 & $0 \%$ \\
Flow & $\mathrm{kg} / \mathrm{s}$ & 15035 & 15035 & $0 \%$ \\
\hline \hline
\end{tabular}

TABLE 2.

THE OUTPUT POWER AS FunCTION OF THE SEA WATER TEMPERATURE

\begin{tabular}{cccc}
\hline \hline No & $\begin{array}{c}\text { Sea Water } \\
\text { Temperature }\left({ }^{\circ} \mathbf{C}\right)\end{array}$ & $\begin{array}{c}\text { Output Power } \\
(\mathbf{k W})\end{array}$ & Deviation \\
\hline 1 & 30 & $230,154.47$ & - \\
2 & 31 & $229,761.42$ & $-0.171 \%$ \\
3 & 32 & $229,365.42$ & $-0.343 \%$ \\
4 & 33 & $228,965.88$ & $-0.516 \%$ \\
5 & 34 & $228,562.67$ & $-0.692 \%$ \\
\hline \hline
\end{tabular}

TABLE 3.

THE CONDENSER PRESSURE AS FUNCTION OF THE SEA WATER TEMPERATURE

\begin{tabular}{cccc}
\hline \hline No & $\begin{array}{c}\text { Sea Water } \\
\text { Temperature }\left({ }^{\circ} \mathbf{C}\right)\end{array}$ & $\begin{array}{c}\text { Condenser } \\
\text { Pressure (bar) }\end{array}$ & Deviation \\
\hline 1 & 30 & 0.08686 & - \\
2 & 31 & 0.09133 & $5.146 \%$ \\
3 & 32 & 0.09600 & $10.523 \%$ \\
4 & 33 & 0.10090 & $16.164 \%$ \\
5 & 34 & 0.10600 & $22.035 \%$ \\
\hline \hline
\end{tabular}

TABLE 4.

THE SYSTEM EFFICIENCY AS FUNCTION OF SEA WATER

\begin{tabular}{cccc}
\multicolumn{4}{c}{ TEMPERATURE } \\
\hline \hline No & $\begin{array}{c}\text { Sea Water } \\
\text { Temperature }\left({ }^{\circ} \mathbf{C}\right)\end{array}$ & $\begin{array}{c}\text { System } \\
\text { efficiency }(\%)\end{array}$ & Deviation \\
\hline 1 & 30 & 33.305 & - \\
2 & 31 & 33.249 & $-0.168 \%$ \\
3 & 32 & 33.190 & $-0.345 \%$ \\
4 & 33 & 33.131 & $-0.522 \%$ \\
5 & 34 & 33.073 & $-0.697 \%$ \\
\hline \hline
\end{tabular}

output power of the steam turbine, condenser pressure and system efficiency respectively. When the table 2 plotted on a graph, as seen in Fig. 2, it gives the variation of net output power as function of cooling water inlet temperature. An increase in cooling water inlet temperature of $1{ }^{\circ} \mathrm{C}, 2{ }^{\circ} \mathrm{C}, 3{ }^{\circ} \mathrm{C}, 4^{\circ} \mathrm{C}\left(31{ }^{\circ} \mathrm{C}-34{ }^{\circ} \mathrm{C}\right)$ correspond to decrease in net output power by $0.171 \%$, $0.343 \%, 0.516 \%$ and $0.692 \%$, respectively.

Based on table 3, Fig. 3 illustrates the condenser pressure as function of cooling water inlet temperature. An increase in cooling water inlet temperature of $1^{\circ} \mathrm{C}$, $2^{\circ} \mathrm{C}, 3{ }^{\circ} \mathrm{C}, 4^{\circ} \mathrm{C}\left(31{ }^{\circ} \mathrm{C}\right.$ to $\left.34{ }^{\circ} \mathrm{C}\right)$ corresponds to increase in condenser pressure by $5.146 \%, 10.523 \%, 16.164 \%$ and $22.035 \%$, respectively.

Fig. 4 shows the system efficiency with cooling water inlet temperature. An increase in cooling water inlet temperature of $1^{\circ} \mathrm{C}, 2^{\circ} \mathrm{C}, 3^{\circ} \mathrm{C}, 4^{\circ} \mathrm{C}\left(31^{\circ} \mathrm{C}-34^{\circ} \mathrm{C}\right)$

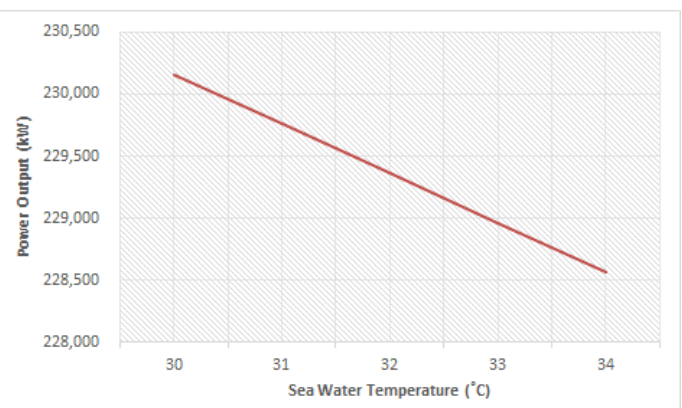

Fig. 2 Variation of output power with cooling water inlet temperature.

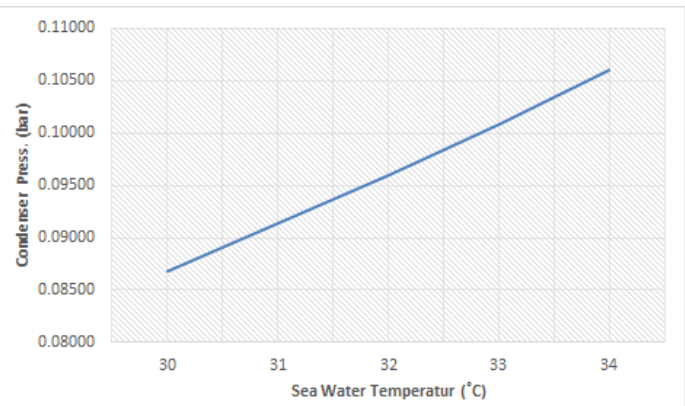

Figure. 3 Variation of condenser pressure with cooling water inlet temperature.

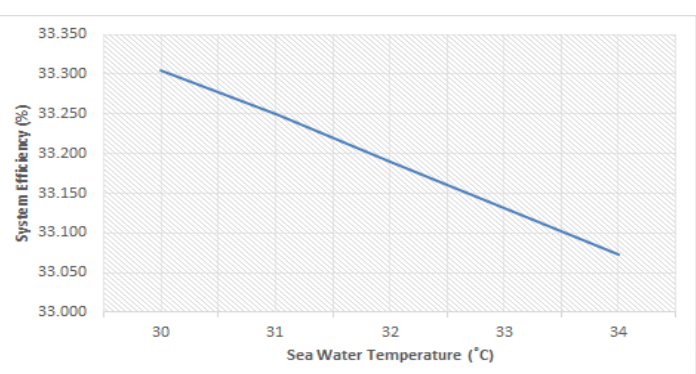

Figure. 4 Variation of system efficiency with cooling water inlet temperature.

corresponds to decrease in system efficiency by $0.168 \%$, $0.345 \%, 0.522 \%$ and $0.697 \%$, respectively.

\section{CONCLUSION}

A heat balance model is developed to determine the functional relationship between the cooling water temperature and condenser pressure also steam turbine output power. The model is developed by using software Cycle-Tempo, based on heat balance data from the manufacturer (manual book).

It can be concluded, that the output power of the plant forecasted decreases by approximately $0.171 \%$ for $1{ }^{\circ} \mathrm{C}$ increase in temperature of the condenser cooling water extracted from the environment. While the condenser pressure forecasted increases by approximately $5.146 \%$ for $1{ }^{\circ} \mathrm{C}$ increase in temperature of the condenser cooling water. And the system efficiency forecasted decreases by approximately $0.168 \%$ for $1{ }^{\circ} \mathrm{C}$ increase in temperature of the condenser cooling water.

\section{AUTHOR's Note}

This paper is actually the preliminary result of our main research about the effects of sea reclamation near Muara Tawar Power Plant on increasing sea water temperatures and its effect on power plant performance. 


\section{REFERENCES}

[1] S. I. Attia, "The influence of condenser cooling water temperature on the thermal efficiency of a nuclear power plant," Annals of Nuclear Energy, vol. 80, pp. 371-378, 2015.

[2] P. Colonna and H. v. Putten, "Dynamic modeling of steam power cycles. Part I-Modeling paradigm and validation," Applied Thermal Engineering, vol. 27, pp. 467-480, 2006.

[3] C. Chen, Z. Zhou, and G. M. Bollas, "Dynamic modeling, simulation and optimization of a subcritical steam power plant. Part I: Plant model and regulatory control," Energy Conversion and Management, vol. 145, pp. 324-334, 2017.

[4] M. Hübel, S. Meinke, M. T. Andrén, C. Wedding, J. Nocke, C. Gierow, et al., "Modelling and simulation of a coal-fired power plant for start-up optimisation," Applied Energy, vol. 208, pp. 319-331, 2017.
[5] N. Woudstra, T. Woudstra, A. Pirone, and T. v. d. Stelt, "Thermodynamic evaluation of combined cycle plants," Energy Conversion and Management, vol. 51, p. 1100, 2010.

[6] B. Fortunato, G. Brunetti, S. M. Camporeale, M. Torresi, and F. Fornarelli, "Thermodynamic model of a downdraft gasifier," Energy Conversion and Management, vol. 140, pp 281-294, 2017.

[7] R. Amirante, P. D. Palma, E. Distaso, M. L. Scala, and P. Tamburrano, "Experimental prototype development and performance analysis of a small-scale combined cycle for energy generation from biomass," Energy Procedia, vol. 126, pp. 659-666, 2017.

[8] P. R. Kumar, V. R. Raju, and N. R. Kumar, "Simulation and parametric optimisation of thermal power plant cycles," Perspectives in Science, vol. 8, pp. 304-406, 2016.

[9] ABB-Power-Generation-Ltd, "Muara Tawar CCPP Hea Balances," pp. 1-8, 1996 